\title{
Advances in COVID-19: the virus, the pathogenesis, and evidence-based control and therapeutic strategies
}

\author{
Guangbiao Zhou $(\bowtie)^{1}$, Saijuan Chen $^{2}$, Zhu Chen $(\bowtie)^{2}$ \\ ${ }^{1}$ State Key Laboratory of Molecular Oncology, National Cancer Center/National Clinical Research Center for Cancer/Cancer Hospital, \\ Chinese Academy of Medical Sciences and Peking Union Medical College, Beijing 100021, China; ${ }^{2}$ State Key Laboratory of Medical \\ Genomics, Shanghai Institute of Hematology, National Research Center for Translational Medicine (Shanghai), Ruijin Hospital Affiliated to \\ Shanghai Jiao Tong University School of Medicine, Shanghai 200025, China
}

(C) Higher Education Press and Springer-Verlag GmbH Germany, part of Springer Nature 2020

\begin{abstract}
Since the outbreak of the COVID-19 pandemic in early December 2019, 81 174 confirmed cases and 3242 deaths have been reported in China as of March 19, 2020. The Chinese people and government have contributed huge efforts to combat this disease, resulting in significant improvement of the situation, with 58 new cases (34 were imported cases) and 11 new deaths reported on March 19, 2020. However, as of March 19, 2020, the COVID-19 pandemic continues to develop in 167 countries/territories outside of China, and 128665 confirmed cases and 5536 deaths have been reported, with 16498 new cases and 817 new deaths occurring in last 24 hours. Therefore, the world should work together to fight against this pandemic. Here, we review the recent advances in COVID-19, including the insights in the virus, the responses of the host cells, the cytokine release syndrome, and the therapeutic approaches to inhibit the virus and alleviate the cytokine storm. By sharing knowledge and deepening our understanding of the virus and the disease pathogenesis, we believe that the community can efficiently develop effective vaccines and drugs, and the mankind will eventually win this battle against this pandemic.
\end{abstract}

Keywords COVID-19; SARS-CoV-2; pathogenesis; evidence-based medicine; control and therapeutic strategies

\section{Introduction}

The past three months have witnessed the tremendous efforts that China has been contributing to tackle the outbreak of the epidemic coronavirus disease 2019 (COVID-19) [1]. These efforts have resulted in the fact that the epidemic peaked on February 19, 2020, and has been declining steadily since then [2]. As of March 19, 2020, 81174 confirmed cases and 3242 deaths were reported in China, including 58 new cases (34 were imported cases) and 11 new deaths reported in the past $24 \mathrm{~h}$ [3]. In contrast, there have been more new cases reported from countries outside of China than from China since February 26, 2020 [4]. The situation of Wuhan is getting better, and all of its Fangcang (makeshift) hospitals have been closed after the last group of patients moved to other

Received March 19, 2020; accepted March 20, 2020

Correspondence: Guangbiao Zhou, gbzhou@ioz.ac.cn; Zhu Chen, zchen@stn.sh.cn hospitals on March 11, 2020 [5]. By March 19, 2020, however, 128665 confirmed cases and 5536 deaths have been reported in 167 countries/territories outside of China, with 16498 new cases and 817 new deaths occurring in the past $24 \mathrm{~h}$ [3]. World Health Organization (WHO) describes SARS-CoV-2 as a pandemic to spur countries to action on March 11, 2020 [6].

\section{An update of the virus}

\section{Genome type}

The SARS-CoV-2 viruses are positive single-stranded RNA viruses [7]. The whole viral architecture was examined by transmission electron microscopy, and the results showed that the virion particles are roughly spherical or moderately pleiomorphic, with spikes as nail-like shape toward outside with a long body embedded in the envelope [8]. Population genetic analyses of 103 SARS-CoV-2 genomes indicate that these viruses evolved 
into leucine (L) and serine (S) types, whereas the L type might be more aggressive and spread more quickly and the $\mathrm{S}$ type might be the ancestral version [9]. While criticisms on this work have been posted [10], other reports indicate that genomic variations of SARS-CoV-2 may lead to multiple outbreak sources of transmission [11,12]. The typing of SARS-CoV-2 can be repeated by other group, though the two clades exhibited similar virulence and clinical outcomes. Analysis of whole genome sequence of 104 strains of the COVID-19 virus isolated from patients in different localities between the end of December 2019 and mid-February 2020 showed $99.9 \%$ homology, without significant mutations [2]. In another study, however, analysis of 120 genomic sequences of SARS-CoV-2 reported that this virus may increase its infectivity through the receptor binding domain recombination and a cleavage site insertion [13]. However, phylogenetic analysis of the SARS-CoV-2 and its closely related reference genomes indicate that the origin of this virus remains to be determined $[9,14]$.

SARS-CoV-like viruses usually have six critical amino acids in the receptor binding domain (RBD) of the spike (S) protein for binding to receptor ACE2 and for determining the host range, and 5 of the 6 amino acids in SARS-CoV-2 differed from SARS-CoV [15]. Moreover, a sequence encoding amino acids PRRA is inserted into the genome of SARS-CoV-2; together with the following R within the original sequence of the $\mathrm{S}$ protein, a polybasic cleavage site (RRAR) at the junction of $\mathrm{S} 1$ and $\mathrm{S} 2$ for Furin protease is generated, making the virus more infectious than SARS-CoV $[15,16]$. Because SARS-CoV2 does not bear any genetic manipulation clue in its genome but exhibits notable features in relationship to coronaviruses in nature, including the optimized RBD and the polybasic cleavage site, any type of laboratory-based scenario of the virus would not be plausible [15].

\section{Cell entry and life cycle}

SARS-CoV-2 uses the SARS-CoV receptor ACE2 for entry and the serine protease TMPRSS2 for S protein priming [17]. The target cells of SARS-CoV-2 have been reportedly to include type II alveolar cells, myocardial cells, proximal tubule cells of kidney, ileum and esophagus epithelial cells, and bladder urothelial cells [18]. According to the SARS-CoV model [19] and recent advances [15,16], SARS-CoV-2 may enter target cells through an endosomal pathway (Fig. 1): S protein binds to ACE2 and is translocated to endosomes, where $\mathrm{S}$ protein is cleaved by the endosomal acid proteases (cathepsin L) to activate its fusion activity. The SARS-CoV-2 S glycoprotein harbors a Furin cleavage site (R-X-X-R; X, any amino acid), facilitating the virus to enter into target cells and making it more infectious than the SARS virus [16]. The SARS$\mathrm{CoV}-2$ genome is released and translated and the protein products are processed by viral proteinases. Meanwhile, the subgenomic negative-strand templates are synthesized and made as a template for genomic RNA. The synthesized genomic RNA assembles with nucleocapsid $(\mathrm{N})$ protein in the cytoplasm to form viral nucleocapsids, which bud into the lumen of the endoplasmic reticulum - Golgi intermediate compartment [19]. The replicated virions are released from the cell through exocytosis to infect other cells (Fig. 1).

\section{The cytokine release syndrome}

\section{Clinical findings}

Clinical studies showed that the most threatened population are the eldly people with non-communicable chronic diseases (NCD, such as cardiocerebrovascular diseases, diabetes, cancer, etc.). In laboratory examinations, sustained decreases in lymphocyte counts are common in COVID-19 patients [20]. In two studies, lymphocytopenia (lymphocyte count $<1.5 \times 10^{9} / \mathrm{L}$ ) was seen in 35 of 99 (35\%) [21] to 97 of $138(70.3 \%)$ [22] patients, respectively. In a recent report of 1099 patients, lymphocytopenia was present in 914 (83.2\%) of the patients on admission [23]. On the other hand, significant elevation of some cytokines is reported in sera or plasma examination. For example, initial plasma concentrations of interleukin-1B (IL-1B), IL-1RA, IL-7, IL-8, IL-9, IL-10, granulocyte colonystimulating factor (G-CSF), granulocyte-macrophage colony-stimulating factor (GM-CSF), interferon $\gamma$ (IFN- $\gamma$ ), interferon $\gamma$-inducible protein (IP10), macrophage inflammatory protein (MIP1), MIP1A, MIP1B, platelet derived growth factor (PDGF), tumor necrosis factor $\alpha(\mathrm{TNF}-\alpha)$, and vascular endothelial growth factor (VEGF) were higher in COVID-19 patients than in healthy adults, and concentrations of IL-2, IL-7, IL-10, G-CSF, IP10, MCP1, MIP1A, and TNF- $\alpha$ were higher in intensive care unit (ICU) patients than non-ICU patients [20]. Another study showed that compared to the mild cases, the severe COVID-19 showed significant decrease in $\mathrm{T}$ cells (especially $\mathrm{CD}^{+} \mathrm{T}$ cells) and increases in IL-6, IL-10, IL-2, and IFN- $\gamma$ levels in the peripheral blood, which gradually recovered in patients who survived the disease $[24,25]$. Moreover, the neutrophil-to-CD8 ${ }^{+} \mathrm{T}$ cell ratio were identified as the most powerful prognostic factor for severe COVID-19 [24]. As compared to healthy controls, COVID-19 patients exhibit significantly higher levels of the exhausted marker PD-1 in their T cells [25]. $\mathrm{CD}^{+}$, $\mathrm{CD}^{+}, \mathrm{CD}^{+} \mathrm{T}$ cells, CD19 ${ }^{+} \mathrm{B}$ cells, and $\mathrm{CD} 16^{+} / \mathrm{CD}^{2} 6^{+}$ NK cells were reduced in COVID-19 patients [26]. $\mathrm{CD}^{-} /$ $\mathrm{CD} 16^{+} / \mathrm{CD} 56^{+} \mathrm{NK}$ cells and $\mathrm{CD}{ }^{+} / \mathrm{CD} 16^{+} / \mathrm{CD} 56^{+} \mathrm{NK} \mathrm{T}$ cells were decreased in 11 COVID-19 with cytokine release syndrome (CRS)-like disease [27]. These results suggest that SARS-CoV-2 may induce CRS in the patients 


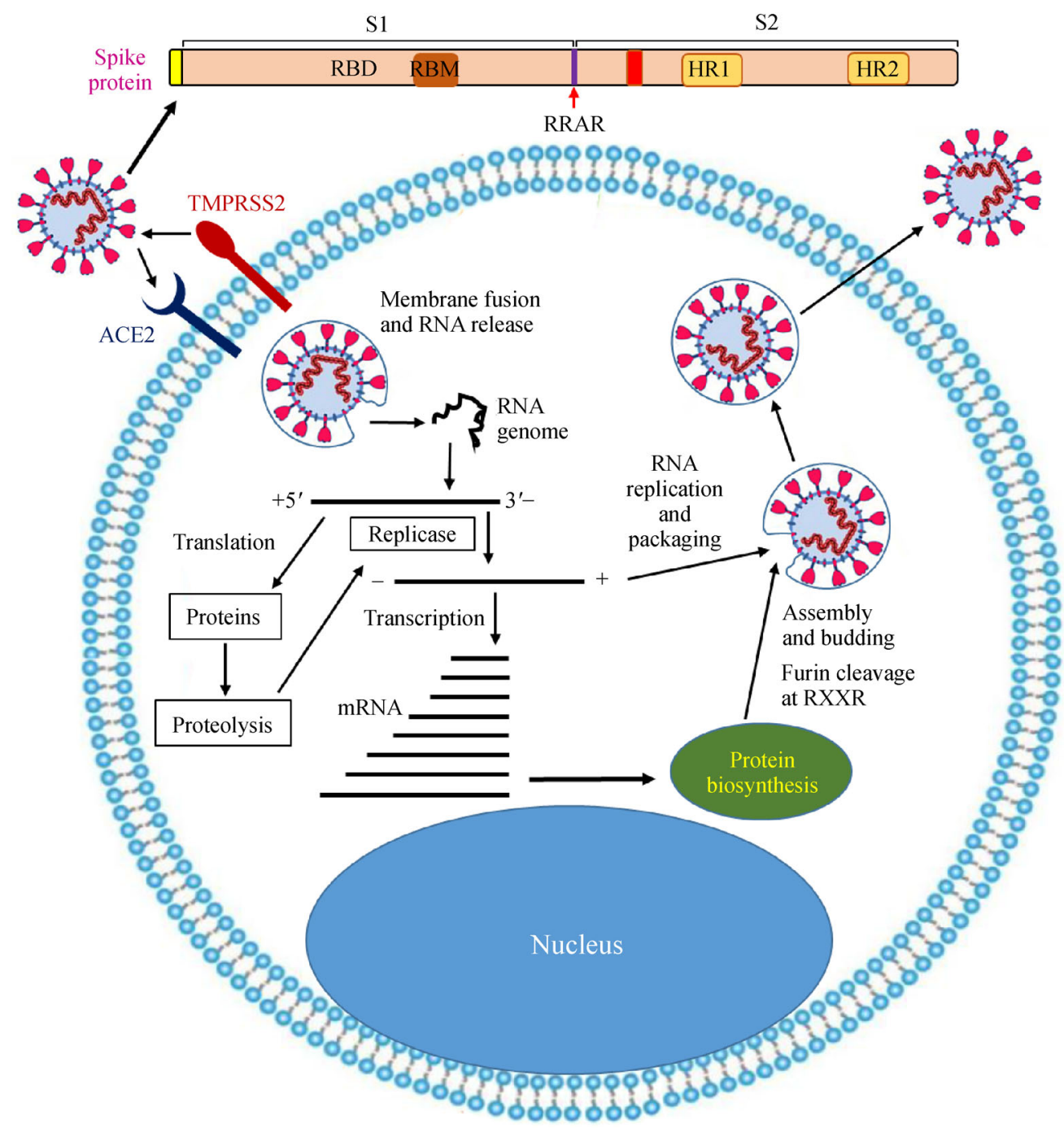

Fig. 1 The putative life cycle of SARS-CoV-2.

(Fig. 2), which is associated with disease severity. Moreover, lymphocytopenia may serve as the risk factor related to cytokine storm and disease severity [20].

\section{Pathogenesis of persistent cytokine release syndrome}

In response to pathogens, the innate immune system releases cytokines to antagonize the pathogens and recruit additional immune responses. CRS, or cytokine storm, is the uncontrolled release of cytokines that can be triggered by a variety of factors including virus, bacterial components, sepsis, superantigens, toxins, antibodies, and chimeric antigen receptor $\mathrm{T}$ cells [28]. CRS was first reported in 1989 when the anti-T cell antibody muromonab-CD3 was used in the treatment of solid organ transplantation [29]. CRS is a life-threatening toxicity that may lead to detrimental effects such as leakage from capillaries, tissue toxicity and edema, organ failure and shock. The syndromes of CRS include sustained fever, hepatomegaly with liver dysfunction, coagulopathy, cytopenia, skin rash, and variable neurologic symptoms (Table 1), which are sometimes difficult to distinguish from those of the underlying diseases [30]. CRS is usually initiated by macrophages, dendritic cell, NK cell, and T cell, in response to pathogen-associated molecular patterns [28]. In SARS-CoV-induced severe disease, the levels of IL-6 was significantly elevated [31]. In influenza virus infection, infiltration of innate immune cells to the lung and the subsequent CRS are the key contributors to morbidity and mortality, whereas the endothelial cells exhibit a central role in orchestration of cytokine amplification [32]. 


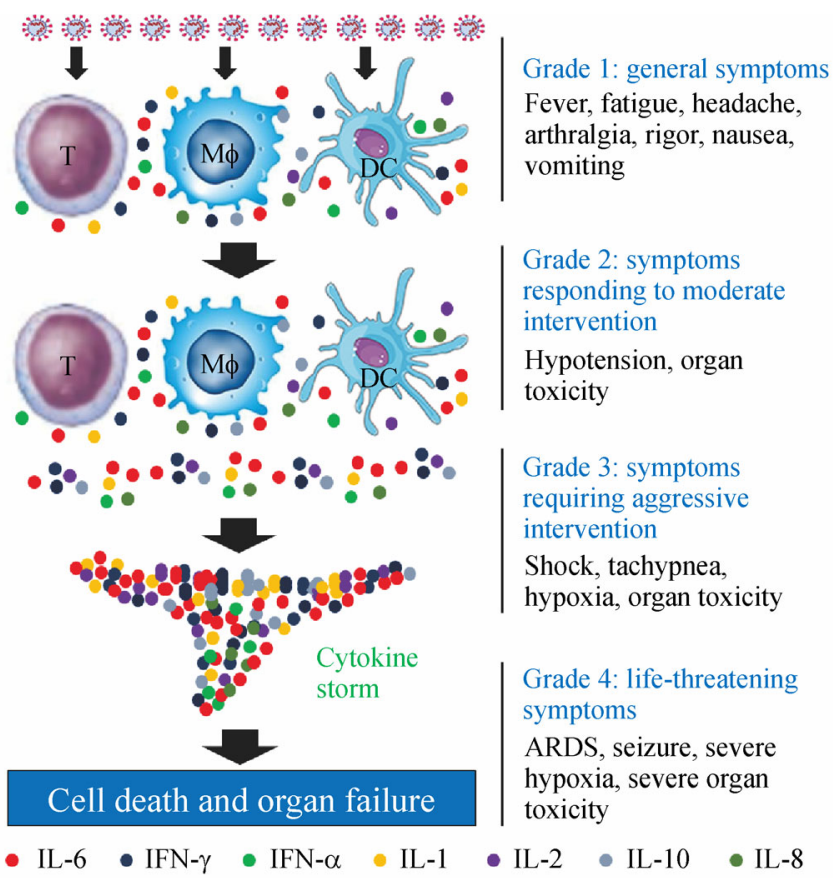

Fig. 2 Cytokine storm and related symptoms of COVID-19.

Table 1 Clinical features of CRS

\begin{tabular}{ll}
\hline Organs/systems & Syndromes \\
\hline General symptoms & Fever, fatigue \\
Blood & Tachypnea, hypoxia, pulmonary edema, respiratory failure \\
Heart & Cytopenias, coagulopathy, febrile neutropenia, disseminated intravascular coagulation \\
Liver & Tachycardia, hypotension, troponin elevation, arrhythmia, QT prolongation, stress, cardiomyopathy, acute heart failure \\
Kidney & Hepatomegaly, elevated liver enzymes, hypofibrinogeniemia, liver failure \\
Central nervous system & Acute kidney injury, renal failure \\
Ileum & Headaches, confusion, hallucinations, delirium, aphasia, paresis, seizures \\
Musculoskeletal system & Diarrhea \\
Stomach & Myalgia, arthralgia, rigor, rash, edema \\
Spleen & Nausea, vomiting \\
\hline
\end{tabular}

\section{Pathogenesis of cytokine release syndrome induced by SARS-Cov-2}

Human coronaviruses can be divided into low pathogenic and highly pathogenic coronaviruses [33], and SARS$\mathrm{CoV}-2$ is obviously a highly pathogenic virus. Clinical studies have shown significant elevation of cytokines and lymphocytopenia in COVID-19. These cytokines include IFN- $\gamma$, TNF- $\alpha$, IL-6, IL-10, IL-2, IL-1, and others. The elevated IL-6 was significantly related to the clinical manifestation of severe type patients [34]. An analysis of dynamic characteristics of host immune system in 3 critical cases showed that hypoxemia severity was closely related with host immune cell levels [35], and the lymphocytopenia and cytotoxicity may be the result of SARS-CoV-2 infection [36]. An observation showed that after SARS$\mathrm{CoV}-2$ infection, $\mathrm{CD}^{+} \mathrm{T}$ lymphocytes are rapidly activated to become pathogenic $\mathrm{T}$ helper (Th) 1 cells and generate cytokines including GM-CSF. The cytokines environment induces inflammatory $\mathrm{CD} 14^{+} \mathrm{CD} 16^{+}$monocytes with high level of IL-6 and accelerates the inflammation. These $\mathrm{T}$ cells and monocytes may enter the pulmonary circulation, where the monocytes become macrophages [9]. These cells, together with other cells 
such as dendritic cells (DCs) [28], trigger CRS [37]. While IFN- $\gamma$ may initiate cytokine storm in SARS patients [38], several cytokines including IL-6 may trigger CRS in COVID-19. Other cells such as natural killer (NK) cells, may also play a role in SARS-CoV-2-induced CRS, and transcription factors such as NF- $\kappa \mathrm{B}$ may play a role in regulating cytokine release.

The consequence of CRS include epithelial and endothelial cell apoptosis and vascular leakage, suboptimal T cell response (impaired virus clearance), accumulation of alternatively activated macrophages and altered tissue homeostasis, acute lung injury, and acute respiratory distress syndrome (ARDS) [33]. CRS is associated with necrosis and tissue destruction and related symptoms such as extensive pulmonary edema, acute bronchopneumonia, alveolar hemorrhage, reactive hemophagocytosis, and ARDS [10] (Fig. 3), which is confirmed by histological examination of COVID-19 patients' lungs [36,39]. The necropsy investigation also shows the infiltration of macrophages and activation of alveolar macrophages in fatal patients. However, whether the CRS results from persistent viral infection of immune cells, for example, alveolar macrophages, or represents the over-activated post-viral infection immune reaction, is worth particular attention.

\section{Control and therapeutics for COVID-19}

\section{Containability of SARS-CoV-2}

The SARS-CoV-2 is a new virus that shares $79.5 \%$ sequence identified to genome sequence of SARS-CoV [40]. The virus exhibits a high reproduction number $\left(\mathrm{R}_{0}\right)$ $[41,42]$, is more infectious and spreads easier between people than the SARS virus probably due to gain of $\mathrm{S}$ glycoprotein Furin-cleavage site [16]. Some people doubted that this virus might be uncontainable and a "let go" policy might be suitable for this pandemic since the cost will be too high to afford strict social distancing and isolation. This notion may be inappropriate for some reasons. Firstly, the historic experience with both SARS and MERS demonstrated that coronavirus with high virulence do have tendency of self-limitation. Secondly, recent studies reported that the asymptomatic cases with transmissibility account for only a small proportion (889/ $72314,1.2 \%$ ) of COVID-19 patient [43]. Thirdly, preliminary data on the recovered cases showed the presence of a very high titer of neutralizing antibodies (39/40 with titer of at least 1:640 while the remaining one had a titer of 1:32 [44]), indicating the high probability of viral clearance in the great majority of infected populations. Thanks to domestic medical workers' great efforts, central and local governments' tremendous input, the contributions from the volunteers and warm-hearted people, and international supports, the spread of SARSCoV-2 in China has been significantly constrained, providing firm evidence that this virus is containable. In some countries outside of China, the policy-makers recognize China's experience in combating COVID-19, while some others decide to apply sound policy of welldesigned containment strategy and to avoid limitation of herd immunity. In extreme cases, use of national machinery including police and armed force is necessary to meet this unprecedented public health crisis.

\section{Anti-virus and CRS-clearing approaches}

In addition to oxygen and other supportive therapeutics, some therapeutics are being tested in clinical trials. On one hand, the anti-virus agents including convalescent patient plasma $[44,45]$ and remdesivir [46] are being tested in clinical trials. In some COVID-19 patients who had viremia, the transfusion of convalescent plasma (CP) from recovered patients significantly reduced the viral load. Recent studies provided evidence that even after viremia, the viral infection may persist in the target organs including lungs, necessitating the CP therapy even in the relatively late stage of severe disease (Personal communication, Prof. Chaofu Wang, Ruijin Hospital Affiliated to Shanghai Jiao Tong University School of Medicine). The structure of the primary target of remdesivir, the RNAdependent RNA polymerase of the virus, has recently been solved [47]. On the other hand, CRS-clearing drugs represent another key remedy to save severe cases. A monoclonal antibody against IL-6 receptor, tocilizumab, is shown to be effective in treating COVID-19. Other approaches to eliminate CRS including antibody against GM-CSF [37], are emerging. Disruption of a selfamplifying catecholamine loop is shown to be able to reduce CRS caused by infections and agents including oncolytic bacteria, T cell-targeting antibodies, and CAR-T cells [48]. Activating with the soluble ligand Slit, an endothelium-specific, Robo4-dependent signaling pathway that strengthens the vascular barrier, diminishes deleterious aspects of CRS-induced organ toxicity [49]. To achieve maximal efficacy, combined usage of anti-viral drugs such as CP and drugs against cytokine storm (Fig. 3), should be considered in clinical trials for severe cases.

\section{Other therapeutic targets and agents}

Vaccines are designed for SARS-CoV-2, and two vaccines are being tested in phase I clinical trials for their safety and immunogenicity in USA and China, respectively. In 12 COVID-19 patients with prophylactic anti-coagulation therapy, an anticoagulant agent dipyridamole (DIP) exerted beneficial effects by reducing viral replication, 


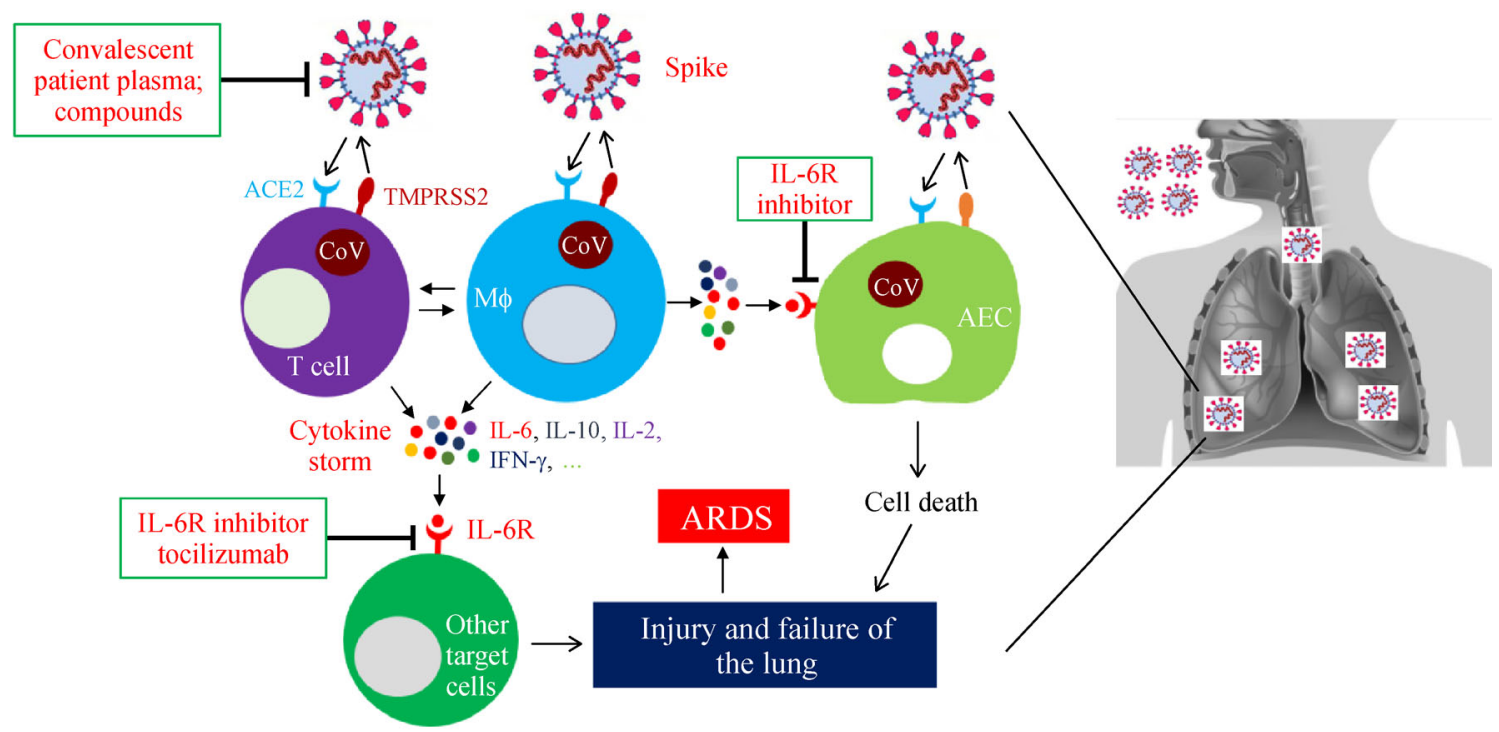

ACE2, angiotensin-converting enzyme 2; AEC, type II alveolar cells; M $\phi$, macrophage

Fig. 3 SARS-CoV-2-induced injury and failure of the lungs, and therapeutic strategies against COVID-19. ARDS, acute respiratory distress syndrome.

suppressing hypercoagulability and enhancing immune recovery [50]. A TMPRSS2 inhibitor approved for clinical use blocked entry and might constitute a treatment option, whereas the sera from convalescent SARS patients crossneutralized SARS-2-S-driven entry [17]. Interferon-inducible lymphocyte antigen 6 complex, locus E (LY6E) inhibits SARS-CoV-2 entry into cells in vitro and in vivo by interfering with spike protein-mediated membrane fusion [51]. Potential therapeutic targets for SARS-CoV2 were analyzed, and inhibitors of 3-chymotrypsin-like protease, spike, RNA-dependent RNA polymerase (RdRp), and papain like protease (PLpro) were screened [52]. The viral 3-chymotrypsin-like cysteine protease enzyme and papain-like protease [53] were used as drug target to screen for lead compounds [54]. A recent trial in 199 COVID-19 patients showed that no benefit was observed with lopinavir-ritonavir treatment beyond standard care [55].

\section{Perspectives}

Owing to the dedication of medical community and evidence-based, responsible policy-making of the Chinese highest level leadership, which won the support of the public, with high appreciation of World Health Organization (WHO) and firm support of international society, the SARS-CoV-2 outbreak has been contained and very effective therapeutic strategies are being developed. However, continued vigilance is needed, and only time can tell whether this virus will disappear in summer or retain in community and whether COVID-19 will become influenza-like disease. Now the virus is rapidly spreading in more than 160 countries/territories outside of China, in some of which the experience of China may be helpful to combat this pandemic. Clinically, more methods should be developed to stop transition of mild cases to severe ones, more effective anti-virus agents should be unveiled, and the harmful effect of CRS should be alleviated to rescue severe cases. With our deepened understanding of the virus and the disease and the development of vaccine and effective drugs, together with the necessary but temporally costing public health intervention measures, we believe that the human life and dignity as the fundamental part of the human rights can be protected and the mankind will eventually win this battle against SARS-CoV-2. Chinese medical community will be working hand-in-hand with colleagues in other countries to fight against the common enemy-COVID-19.

\section{Acknowledgements}

This work was supported by the Key Project of the National Natural Science Foundation of China (No. 81830093), the CAMS Innovation Fund for Medical Sciences (CIFMS) (No. 2019-I2M-1-003), Double First-Class Project (No. WF510162602) and State Key Laboratory of Medical Genomics of Shanghai Jiao Tong University, Overseas Expertise Introduction Project for Discipline Innovation (111 Project) (No. B17029). The study sponsors had no role in the design of the study; the data collection, analysis, or interpretation; the writing of the article; or the decision to submit for publication. 


\section{Compliance with ethics guidelines}

Guangbiao Zhou, Saijuan Chen, and Zhu Chen declare no conflict of interests. This manuscript does not involve a research protocol requiring approval by the relevant institutional review board or ethics committee.

\section{References}

1. Yan R, Zhang Y, Li Y, Xia L, Guo Y, Zhou Q. Structural basis for the recognition of the SARS-CoV-2 by full-length human ACE2. Science 2020 Mar 4. [Epub ahead of print] doi: 10.1126/science. abb2762

2. World Health Organization. Report of the WHO-China Joint Mission on Coronavirus Disease 2019 (COVID-19). 2020. https:// www.who.int/docs/default-source/coronaviruse/who-china-jointmission-on-covid-19-final-report.pdf (accessed February 27, 2020)

3. World Health Organization. Coronavirus disease 2019 (COVID-19) Situation Report - 59. March 19, 2020. https://www.who.int/docs/ default-source/coronaviruse/situation-reports/20200319-sitrep-59covid-19.pdf?sfvrsn = c3dcdef9_2 (accessed March 20, 2020)

4. World Health Organization. Coronavirus disease 2019 (COVID-19) Situation Report - 37. February 26, 2020. https://www.who.int/ docs/default-source/coronaviruse/situation-reports/20200226sitrep-37-covid-19.pdf?sfvrsn $=2146841$ e_2 (accessed February 27, 2020)

5. Zhang Y, Cao D. Wuhan to close its largest makeshift hospital. China Daily. March 7, 2020. https://www.chinadaily.com.cn/a/ 202003/07/WS5e63a721a31012821727d2a9.html (accessed March $8,2020)$

6. World Health Organization. WHO Director-General's opening remarks at the media briefing on COVID-19 - 11 March 2020. March 11, 2020. https://www.who.int/dg/speeches/detail/whodirector-general-s-opening-remarks-at-the-media-briefing-oncovid-19-11-march-2020 (accessed March 12, 2020)

7. Kannan S, Shaik Syed Ali P, Sheeza A, Hemalatha K. COVID-19 (novel coronavirus 2019) - recent trends. Eur Rev Med Pharmacol Sci 2020; 24(4): 2006-2011

8. Wang M, Cao R, Zhang L, Yang X, Liu J, Xu M, Shi Z, Hu Z, Zhong W, Xiao G. Remdesivir and chloroquine effectively inhibit the recently emerged novel coronavirus (2019-nCoV) in vitro. Cell Res 2020; 30(3): 269-271

9. Tang X, Wu C, Li X, Song Y, Yao X, Wu X, Duan Y, Zhang H, Wang Y, Qian Z, Cui J, Lu J. On the origin and continuing evolution of SARS-CoV-2. Natl Sci Rev 2020 Mar 3. [Epub ahead of print] doi:10.1093/nsr/nwaa036

10. Maclean OA, Orton R, Singer J, Robertson DL. Response to "On the origin and continuing evolution of SARS-CoV-2". 2020. http:// virological.org/t/response-to-on-the-origin-and-continuing-evolution-of-sars-cov-2/418 (accessed March 7, 2020)

11. Zhang L, Yang J-R, Zhang Z, Lin Z. Genomic variations of SARSCoV-2 suggest multiple outbreak sources of transmission. medRxiv 2020; doi: 10.1101/2020.02.25.20027953

12. Ceraolo C, Giorgi FM. Genomic variance of the 2019-nCoV coronavirus. J Med Virol 2020; 92: 522-528

13. Wu A, Niu P, Wang L, Zhou H, Zhao X, Wang W, et al. Mutations, recombination and insertion in the evolution of 2019-nCoV. bioRxiv 2020; doi: 10.1101/2020.02.29.971101

14. Yu WB, Tang GD, Zhang L, Corlett RT. Decoding evolution and transmissions of novel pneumonia coronavirus using the whole genomic data. ChinaXiv 2020. http://www.chinaxiv.org/abs/ 202002.00033 (accessed March 19, 2020)

15. Andersen KG, Rambaut A, Lipkin WI, Holmes EC, Garry RF. The proximal origin of SARS-CoV-2. Nat Med 2020. [Epub ahead of print] doi: 10.1038/s41591-020-0820-9

16. Liu H, Wu C, Yang Y, Liu Y, Zhang P, Wang Y, Wang Q, et al. Furin, a potential therapeutic target for COVID-19. ChinaXiv 2020. http://www.chinaxiv.org/abs/202002.00062 (accessed March 19, 2020)

17. Hoffmann M, Kleine-Weber H, Schroeder S, Krüger N, Herrler T, Erichsen S, Schiergens TS, Herrler G, Wu NH, Nitsche A, Müller MA, Drosten C, Pöhlmann S. SARS-CoV-2 cell entry depends on ACE2 and TMPRSS2 and is blocked by a clinically proven protease inhibitor. Cell 2020 Mar 4. [Epub ahead of print] doi: 10.1016/j. cell.2020.02.052

18. Zou X, Chen K, Zou J, Han P, Hao J, Han Z. The single-cell RNAseq data analysis on the receptor ACE2 expression reveals the potential risk of different human organs vulnerable to 2019-nCoV infection. Front Med 2020 Mar 12. [Epub ahead of print] doi: 10.1007/s11684-020-0754-0

19. Du L, He Y, Zhou Y, Liu S, Zheng BJ, Jiang S. The spike protein of SARS-CoV - a target for vaccine and therapeutic development. Nat Rev Microbiol 2009; 7(3): 226-236

20. Lu R, Zhao X, Li J, Niu P, Yang B, Wu H, Wang W, Song H, Huang B, Zhu N, Bi Y, Ma X, Zhan F, Wang L, Hu T, Zhou H, Hu Z, Zhou W, Zhao L, Chen J, Meng Y, Wang J, Lin Y, Yuan J, Xie Z, Ma J, Liu WJ, Wang D, Xu W, Holmes EC, Gao GF, Wu G, Chen W, Shi W, Tan W. Genomic characterisation and epidemiology of 2019 novel coronavirus: implications for virus origins and receptor binding. Lancet 2020; 395(10224): 565-574

21. Chen N, Zhou M, Dong X, Qu J, Gong F, Han Y, Qiu Y, Wang J, Liu Y, Wei Y, Xia J, Yu T, Zhang X, Zhang L. Epidemiological and clinical characteristics of 99 cases of 2019 novel coronavirus pneumonia in Wuhan, China: a descriptive study. Lancet 2020; 395 (10223): 507-513

22. Wang D, Hu B, Hu C, Zhu F, Liu X, Zhang J, Wang B, Xiang H, Cheng Z, Xiong Y, Zhao Y, Li Y, Wang X, Peng Z. Clinical characteristics of 138 hospitalized patients with 2019 novel coronavirus-infected pneumonia in Wuhan, China. JAMA 2020; 323(11): 1061

23. Guan WJ, Ni ZY, Hu Y, Liang WH, Ou CQ, He JX, Liu L, Shan H, Lei CL, Hui DSC, Du B, Li LJ, Zeng G, Yuen KY, Chen RC, Tang CL, Wang T, Chen PY, Xiang J, Li SY, Wang JL, Liang ZJ, Peng YX, Wei L, Liu Y, Hu YH, Peng P, Wang JM, Liu JY, Chen Z, Li G, Zheng ZJ, Qiu SQ, Luo J, Ye CJ, Zhu SY, Zhong NS; China Medical Treatment Expert Group for Covid-19. Clinical characteristics of coronavirus disease 2019 in China. N Engl J Med 2020 Feb 28. [Epub ahead of print] doi: 10.1056/NEJMoa2002032

24. Liu J, Li S, Liu J, Liang B, Wang X, Wang H, et al. Longitudinal characteristics of lymphocyte responses and cytokine profiles in the peripheral blood of SARS-CoV-2 infected patients. medRxiv 2020; doi: 10.1101/2020.02.16.20023671

25. Diao B, Wang C, Tan Y, Chen X, Liu Y, Ning L, et al. Reduction and functional exhaustion of $\mathrm{T}$ cells in patients with coronavirus 
disease 2019 (COVID-19). medRxiv 2020; doi: 10.1101/ 2020.02.18.20024364

26. Zhang Z, Li X, Zhang W, Shi ZL, Zheng Z, Wang T. Clinical features and treatment of 2019-nCov pneumonia patients in Wuhan: report of a couple cases. Virol Sin 2020 Feb 7. [Epub ahead of print] doi: $10.1007 / \mathrm{s} 12250-020-00203-8$

27. Wang W, He J, Lie P, Huang L, Wu S, Lin Y, et al. The definition and risks of cytokine release syndrome-like in 11 COVID-19infected pneumonia critically ill patients: disease characteristics and retrospective analysis. medRxiv 2020; doi: 10.1101/2020.02.26. 20026989

28. Nazinitsky A, Rosenthal KS. Cytokine storms: systemic disasters of infectious diseases. Infect Dis Clin Pract 2010; 18(3): 188-192

29. Chatenoud L, Ferran C, Reuter A, Legendre C, Gevaert Y, Kreis H, Franchimont P, Bach JF. Systemic reaction to the anti-T-cell monoclonal antibody OKT3 in relation to serum levels of tumor necrosis factor and interferon- $\gamma$ [corrected]. N Engl J Med 1989; 320 (21): $1420-1421$

30. Behrens EM. Cytokines in cytokine storm syndrome. In: Cron RQ, Behrens EM. Cytokine Storm Syndrome. Cham: Springer International Publishing, 2019. 197-207

31. Okabayashi T, Kariwa H, Yokota S, Iki S, Indoh T, Yokosawa N, Takashima I, Tsutsumi H, Fujii N. Cytokine regulation in SARS coronavirus infection compared to other respiratory virus infections. J Med Virol 2006; 78(4): 417-424

32. Teijaro JR, Walsh KB, Cahalan S, Fremgen DM, Roberts E, Scott F, Martinborough E, Peach R, Oldstone MB, Rosen H. Endothelial cells are central orchestrators of cytokine amplification during influenza virus infection. Cell 2011; 146(6): 980-991

33. Channappanavar R, Perlman S. Pathogenic human coronavirus infections: causes and consequences of cytokine storm and immunopathology. Semin Immunopathol 2017; 39(5): 529-539

34. Liu T, Zhang J, Yang Y, Ma H, Li Z, Zhang J, et al. The potential role of IL-6 in monitoring severe case of coronavirus disease 2019. medRxiv 2020; doi: 10.1101/2020.03.01.20029769

35. Yu L, Tong Y, Shen G, Fu A, Lai Y, Zhou X, et al. Immunodepletion with hypoxemia: a potential high risk subtype of coronavirus disease 2019. medRxiv 2020; doi: 10.1101/2020. 03.03.20030650

36. Xu Z, Shi L, Wang Y, Zhang J, Huang L, Zhang C, Liu S, Zhao P, Liu H, Zhu L, Tai Y, Bai C, Gao T, Song J, Xia P, Dong J, Zhao J, Wang FS. Pathological findings of COVID-19 associated with acute respiratory distress syndrome. Lancet Respir Med 2020 Feb 18. [Epub ahead of print] doi: 10.1016/S2213-2600(20)30076-X

37. Zhou Y, Fu B, Zheng X, Wang D, Zhao C, Qi Y, et al. Aberrant pathogenic $\mathrm{GM}_{-} \mathrm{CSF}^{+} \mathrm{T}$ cells and inflammatory $\mathrm{CD} 14^{+} \mathrm{CD} 16^{+}$ monocytes in severe pulmonary syndrome patients of a new coronavirus. bioRxiv 2020; doi: 10.1101/2020.02.12.945576

38. Huang KJ, Su IJ, Theron M, Wu YC, Lai SK, Liu CC, Lei HY. An interferon- $\gamma$-related cytokine storm in SARS patients. J Med Virol 2005; 75(2): 185-194

39. Luo W, Yu H, Gou J, Li X, Sun Y, Li J, Liu L. Clinical pathology of critical patient with novel coronavirus pneumonia (COVID-19). Preprints 2020; 2020020407 https://www.preprints.org/manuscript/ 202002.0407/v4 (accessed March 19, 2020)

40. Zhou P, Yang XL, Wang XG, Hu B, Zhang L, Zhang W, Si HR, Zhu Y, Li B, Huang CL, Chen HD, Chen J, Luo Y, Guo H, Jiang RD, Liu
MQ, Chen Y, Shen XR, Wang X, Zheng XS, Zhao K, Chen QJ, Deng F, Liu LL, Yan B, Zhan FX, Wang YY, Xiao GF, Shi ZL. A pneumonia outbreak associated with a new coronavirus of probable bat origin. Nature 2020; 579(7798): 270-273

41. Anastassopoulou C, Russo L, Tsakris A, Siettos C. Data-based analysis, modelling and forecasting of the novel coronavirus (2019nCoV) outbreak. medRxiv 2020; doi: 10.1101/2020.02.11. 20022186

42. Li Q, Guan X, Wu P, Wang X, Zhou L, Tong Y, Ren R, Leung KSM, Lau EHY, Wong JY, Xing X, Xiang N, Wu Y, Li C, Chen Q, Li D, Liu T, Zhao J, Liu M, Tu W, Chen C, Jin L, Yang R, Wang Q, Zhou S, Wang R, Liu H, Luo Y, Liu Y, Shao G, Li H, Tao Z, Yang Y, Deng Z, Liu B, Ma Z, Zhang Y, Shi G, Lam TTY, Wu JTK, Gao GF, Cowling BJ, Yang B, Leung GM, Feng Z. Early transmission dynamics in Wuhan, China, of novel coronavirus-infected pneumonia. N Engl J Med 2020 Jan 29. [Epub ahead of print] doi: 10.1056/ NEJMoa2001316

43. Novel Coronavirus Pneumonia Emergency Response Epidemiology Team. The epidemiological characteristics of an outbreak of 2019 novel coronavirus diseases (COVID-19) in China. Chin J Epidemiol (Zhonghua Liu Xing Bing Xue Za Zhi) 2020; 41(2): 145-151 (in Chinese)

44. Duan K, Liu B, Li C, Zhang H, Yu T, Qu J, et al. The feasibility of convalescent plasma therapy in severe COVID-19 patients: a pilot study. Proc Natl Acad Sci USA 2020; doi: 10.1073/ pnas.2004168117

45. Chen L, Xiong J, Bao L, Shi Y. Convalescent plasma as a potential therapy for COVID-19. Lancet Infect Dis 2020 Feb 27. [Epub ahead of print] doi: 10.1016/S1473-3099(20)30141-9

46. Holshue ML, DeBolt C, Lindquist S, Lofy KH, Wiesman J, Bruce H, Spitters C, Ericson K, Wilkerson S, Tural A, Diaz G, Cohn A, Fox L, Patel A, Gerber SI, Kim L, Tong S, Lu X, Lindstrom S, Pallansch MA, Weldon WC, Biggs HM, Uyeki TM, Pillai SK; Washington State 2019-nCoV Case Investigation Team. First case of 2019 novel coronavirus in the United States. N Engl J Med 2020; 382(10): 929-936

47. Zhu N, Zhang D, Wang W, Li X, Yang B, Song J, Zhao X, Huang B, Shi W, Lu R, Niu P, Zhan F, Ma X, Wang D, Xu W, Wu G, Gao GF, Tan W; China Novel Coronavirus Investigating and Research Team. A novel coronavirus from patients with pneumonia in China, 2019. N Engl J Med 2020; 382(8): 727-733

48. Staedtke V, Bai RY, Kim K, Darvas M, Davila ML, Riggins GJ, Rothman PB, Papadopoulos N, Kinzler KW, Vogelstein B, Zhou S. Disruption of a self-amplifying catecholamine loop reduces cytokine release syndrome. Nature 2018; 564(7735): 273-277

49. London NR, Zhu W, Bozza FA, Smith MCP, Greif DM, Sorensen LK, et al. Targeting Robo4-dependent Slit signaling to survive the cytokine storm in sepsis and influenza. Sci Transl Med 2010; 2(23): 23ra19

50. Liu X, Li Z, Liu S, Chen Z, Zhao Z, Huang YY, et al. Therapeutic effects of dipyridamole on COVID-19 patients with coagulation dysfunction. medRxiv 2020; doi: 10.1101/2020.02.27.20027557

51. Pfaender S, Mar KB, Michailidis E, Kratzel A, Hirt D, V'kovski P, et al. LY6E impairs coronavirus fusion and confers immune control of viral disease. bioRxiv 2020; doi: 10.1101/2020.03.05.979260

52. Wu C, Liu Y, Yang Y, Zhang P, Zhong W, Wang Y, Wang Q, Xu Y, Li M, Li X, Zheng M, Chen L, Li H. Analysis of therapeutic targets 
for SARS-CoV-2 and discovery of potential drugs by computational methods. Acta Pharm Sin B 2020 Feb 27. [Epub ahead of print] doi:10.1016/j.apsb.2020.02.008

53. Rimanshee A, Amit D, Vishal P, Mukesh K. Potential inhibitors against papain-like protease of novel coronavirus (SARS-CoV-2) from FDA approved drugs. ChemRxiv 2020; doi: 10.26434/ chemrxiv.11860011.v2

54. Tahir ulQamar M, Alqahtani S, Alamri M, Chen L. Structural basis of SARS-CoV-2 3CLpro and anti-COVID-19 drug discovery from medicinal plants. Preprints 2020; 2020020193 https://www.preprints.org/manuscript/202002.0193/v1 (accessed March 19, 2020)
55. Cao B, Wang Y, Wen D, Liu W, Wang J, Fan G, Ruan L, Song B, Cai Y, Wei M, Li X, Xia J, Chen N, Xiang J, Yu T, Bai T, Xie X, Zhang L, Li C, Yuan Y, Chen H, Li H, Huang H, Tu S, Gong F, Liu Y, Wei Y, Dong C, Zhou F, Gu X, Xu J, Liu Z, Zhang Y, Li H, Shang L, Wang K, Li K, Zhou X, Dong X, Qu Z, Lu S, Hu X, Ruan S, Luo S, Wu J, Peng L, Cheng F, Pan L, Zou J, Jia C, Wang J, Liu X, Wang S, Wu X, Ge Q, He J, Zhan H, Qiu F, Guo L, Huang C, Jaki T, Hayden FG, Horby PW, Zhang D, Wang C. A trial of lopinavirritonavir in adults hospitalized with severe COVID-19. N Engl J Med 2020 Mar 18. [Epub ahead of print] doi: 10.1056/ NEJMoa2001282 